(2)

OPEN ACCESS

\title{
Acute pancreatitis due to a Bochdalek hernia in an adult patient
}

\author{
Valeria Tonini, Guglielmo Gozzi, Maurizio Cervellera
}

Emergency Surgery Unit, St Orsola Hospital, University of Bologna, Bologna, Italy

Correspondence to Professor Valeria Tonini, valeria.tonini@unibo.it

Accepted 17 January 2018

\section{DESCRIPTION}

A 27-year-old man was admitted to the emergency room because of a violent epigastric pain that started a few hours earlier during intense physical exercise. The same symptomatology had also occurred 3 days earlier, while engaging in sports, but disappeared spontaneously. Despite the severe, painful clinical picture, the abdomen was treatable by palpation. Laboratory exams recorded abnormal leucocyte count $12 \times 10^{9} / \mathrm{L}$, amylase level $667 \mathrm{U} / \mathrm{L}$ and lipase level $1602 \mathrm{U} / \mathrm{L}$.

A chest and abdominal X-ray showed diaphragmatic herniation of the bowel's loops in the left thorax with both the cardiac shadow and mediastinum dislocated to the right. Once the patient was informed of the results, he reported being already diagnosed with diaphragmatic hernia during childhood, although no other investigations were performed back then. He had a history neither of trauma nor of other causes of pancreatitis. A CT scan revealed the herniation of the stomach, spleen, bowel's loops and transverse colon, whereas the left lung resulted crushed and atelectatic (figure 1). The pancreas showed to be dragged upward with a hypodense and globose aspect of the body with peripancreatic fluid. Such elements were compatible with pancreatitis.

At first, the patient was treated conservatively. A nasogastric tube was placed, and resulted in little symptomatic relief of his pain. However, during the next 12 hours, he continued to have large nasogastric aspirates whereas the pain became uncontrolled.

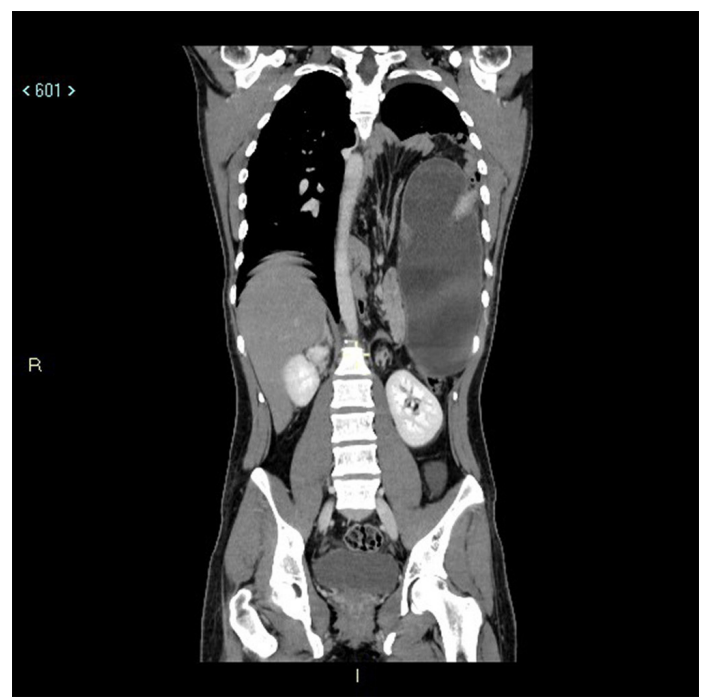

Figure 1 CT scan showing enormous herniation of the abdominal organs into the thorax.
Then an emergency laparotomy was performed. The stomach, spleen, small intestine, transverse colon and omentum were found displaced in the thorax through a gigantic left posterolateral hernia of Bochdalek (figure 2). Since the pancreas was stretched towards the thoracic cavity, it appeared increased in volume and covered by wax stains, pathognomonic signs of pancreatitis. The spleen resulted rather enlarged probably due to a congestive state. While the contents of the hernia were carefully reduced into the abdomen, the left lung rapidly expanded. The diaphragmatic defect was repaired with interrupted non-adsorbable stitches without a mesh. Apart from a left pulmonary thickening treated with antibiotics, the postoperative course was uneventful and he was discharged 2 weeks later. The postoperative CT scan was normal.

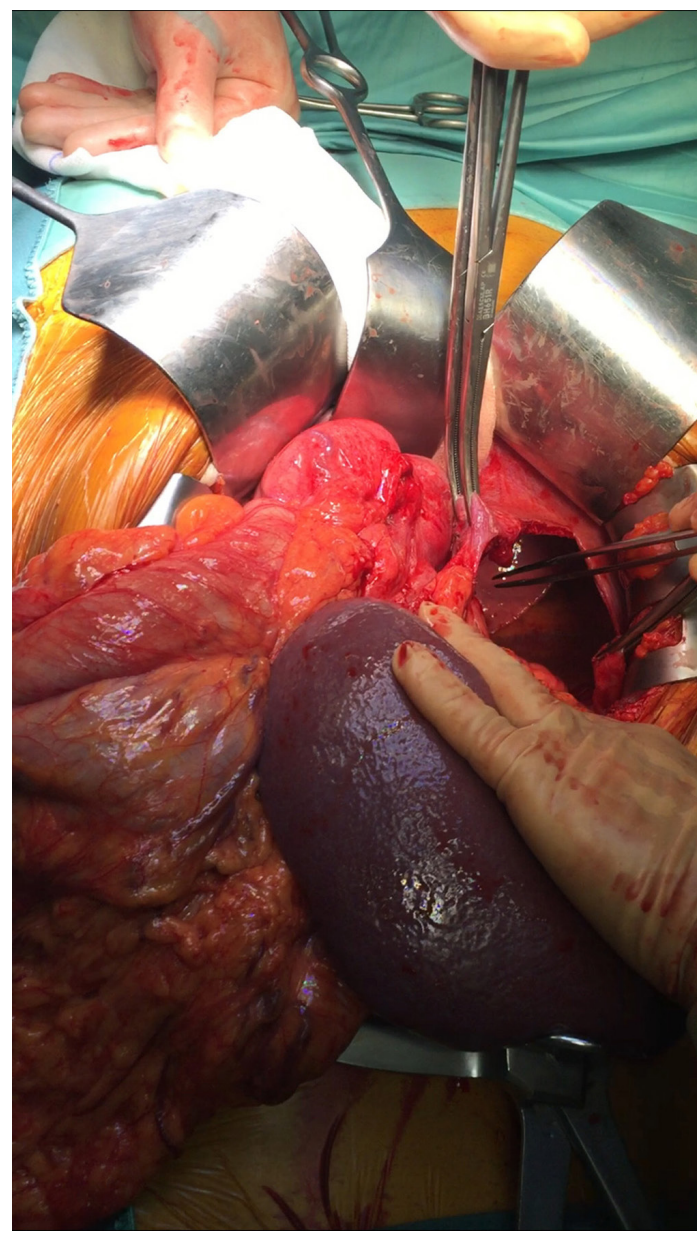

Figure 2 The wide gap through which the herniation occurred and some of the herniated viscera. 
Bochdalek hernia is the most widespread type of congenital diaphragmatic hernia, and it occurs when the posterolateral diaphragmatic foramina fail to fuse appropriately. If the gap is tiny, the hernia may remain undiagnosed for years. Presentation in adults is rare, but may be caused by raised abdominal pressure in patients experiencing obesity, pregnancy or intense exertionas in this patient.

\section{Patient's perspective}

If my parents and I had been correctly informed about my illness, we could have chosen an elective surgery avoiding acute severe complications.

\section{Learning points}

Acute pancreatitis could be considered an exceptional complication of Bochdalek hernia.

- Even if a conservative approach is preferred when facing a diagnosis of pancreatitis, in this particular type due to a mechanical traction on the pancreas, timing of surgery should be carefully considered.

- When the diagnosis of diaphragmatic hernia is made, elective surgery should be considered in order to avoid higher risks of an emergency operation.

- Parents of a child diagnosed with diaphragmatic hernia should be well educated about the possibility of acute complications and the necessity of a strict follow-up.

- In patients with diaphragmatic hernia, intense exertion should be avoided.
While cases with gastrointestinal symptoms are well documented, its presentation with pancreatitis is exceptional, in fact only eight reports can be found in the literature. ${ }^{1-3}$

Even if a conservative approach is preferred in pancreatitis, in this particular type, an emergency operation should be considered on the basis of the following factors: gravity of symptomatology, consequences of a prolonged pulmonary collapse and, above all, the mechanical origin of pancreatitis. The traction on the pancreas, due to acute distension and volvulus of the stomach, could be solved with an emergency operation, whereas its persistence could aggravate the pancreatitis.

Contributors VT and MC operated the patient. VT and GG wrote the case report and acquired the clinical photographs.

Competing interests None declared.

Patient consent Obtained.

Provenance and peer review Not commissioned; externally peer reviewed.

Open Access This is an Open Access article distributed in accordance with the Creative Commons Attribution Non Commercial (CC BY-NC 4.0) license, which permits others to distribute, remix, adapt, build upon this work non-commercially, and license their derivative works on different terms, provided the original work is properly cited and the use is non-commercial. See: http://creativecommons.org/ licenses/by-nc/4.0/

(C) BMJ Publishing Group Ltd (unless otherwise stated in the text of the article) 2018. All rights reserved. No commercial use is permitted unless otherwise expressly granted.

\section{REFERENCES}

1 Cuschieri RJ, Wilson WA. Incarcerated Bochdalek hernia presenting as acute pancreatitis. Br J Surg 1981;68:669.

2 Harrington DK, Curran FT, Morgan I, et al. Congenital Bochdalek hernia presenting with acute pancreatitis in an adult. J Thorac Cardiovasc Surg 2008;135:1396-7.

3 Angel MA, David CP, Laura MA, et al. Bochdalek hernia and repetitive pancreatitis in a 33 year old woman. Int J Surg Case Rep 2014;5:743-5.

Copyright 2018 BMJ Publishing Group. All rights reserved. For permission to reuse any of this content visit http://group.bmj.com/group/rights-licensing/permissions.

BMJ Case Report Fellows may re-use this article for personal use and teaching without any further permission.

Become a Fellow of BMJ Case Reports today and you can:

- Submit as many cases as you like

- Enjoy fast sympathetic peer review and rapid publication of accepted articles

- Access all the published articles

- Re-use any of the published material for personal use and teaching without further permission

For information on Institutional Fellowships contact consortiasales@bmjgroup.com

Visit casereports.bmj.com for more articles like this and to become a Fellow 